\title{
Influence of traditional settlement patterns on urban design and planning: A case study of Zaria, Nigeria
}

This article discusses the influence of traditional settlement patterns on planning new parts of towns using the case study of the old town of Zaria, Nigeria, which developed from the eleventh to nineteenth centuries. The central argument is that some elements of old settlement patterns have been integrated into Zaria's new town. The literature review traces the evolution of the city, reflecting on traditional Hausa architecture, settlement forms, and their influence on spatial organization. Maps, sketches, and tables are used to illustrate how the rich Hausa tra- dition has influenced urban design and planning. The study shows that some traditional settlement patterns influenced urban design because old vernacular architecture was gradually integrated into new town plans. The article concludes that architects, planners, and developers can learn from this case study of Zaria.

Keywords: traditional settlements, vernacular architecture, urban design and planning, Hausa culture 


\section{Introduction}

Dwellings meet people's basic needs, especially shelter, security, and comfort. According to Astrolabe (2002), the practical establishment of homes through the selection of sites, planning, and construction differs from one country to another (Dobronravin, 2013; Barau et al., 2015). Regarding settlements, Dmochowski (1990), indicated that modern forms of housing developments can integrate traditional architecture and settlement patterns to blend and shape modern forms of settlements in general. Many ethnic and geographical areas, including the central, eastern, and southern regions of Nigeria, have distinct traditional architectural and settlement forms. However, the traditional architecture of Hausa settlements is unique (Buchanan \& Pugh, 1995). The spatial configuration of Hausa dwellings and open space allocation systems evolved over generations, incorporating various trends in civilization, culture, and tradition. Olotuah (2000) indicates that certain forms of architecture can be specific to a certain ethnic group of people, thereby influencing settlement layouts. For example, the Egyptians, Greeks, and Romans had architecture for specific functions (Hutchison \& Sterbenz, 2018). Similarly, the Hausa people of Zaria in northern Nigeria are known for their unique vernacular architecture, in which the design of buildings reflected the people's social values (Rowan, 1981). Zaria is an example of a historical Hausa settlement, in which external factors such as the climate, the site, and social needs influenced the choice of local materials, techniques, and decorations. This determined the size and relationship of the rooms and the spatial organization of the houses. According to Denyer (1978), these factors were the foundation of traditional and/or vernacular architecture specific to the Hausa people of Zaria. This article reviews the settlement forms and patterns of the Hausa people of Zaria. It analyses traditional architecture to highlight the distinct urban design and spatial planning concepts that town planners, architects, and developers can then incorporate into current urban design and planning projects.

This study explores the influence of traditional settlement patterns on planning new parts of towns using the case study of Zarias's old town, which developed from the eleventh to nineteenth centuries. The following questions are examined:

1) What is the historical narrative explaining the development of traditional Hausa settlement and architectural patterns?

2) What factors influenced the spatial arrangements, patterns, and layout of Hausa settlements?

3) What are the perceptions of the influence of traditional settlements and architecture in Zaria on integrating old and new settlements in contemporary urban design and planning?

\section{Materials and methods}

This section describes the choice of the study area and similar past and current studies. The rationale for the data collection method is also outlined. Zaria was chosen because it is a typical example of what town planners and others can learn from the rich Hausa tradition of architecture, settlement pattern, and spatial organization. The data collection method used is similar to that in studies by Faludi (1979), Taylor (1998), and Deckro and Hebert (2003). It "combines ethnography and the paradigm of planning theory that looks at traditional and current approaches to architecture, settlement patterns and town planning." The research method therefore shows how traditional Hausa settlement influenced urban design and planning in Zaria.

\subsection{Choice of study area and data collection}

Zaria's old city has most of the characteristics of a typical Hausa settlement and is one of the best examples of traditional town planning in West Africa. In line with the ethnographic methods of engaging and interacting with communities in historical settlement studies (e.g. Ibrahim, 2015 and Narayanan, 2015), residents of Zaria were consulted to collect primary data. Secondary information and primary data were needed to understand the influence of traditional Hausa settlement forms on architecture, town planning, and spatial organization. Data collection was carried out in two stages:

- Stage one: Secondary data were collected by examining oral traditions and published data. Records were consulted, particularly articles by experts on traditional Hausa architecture and settlement patterns. Library records from Zaria and Ahmadu Bello University of Zaria were also accessed.

- Stage two: Primary data were collected from key informants. These included traditional leaders, elders, traders, public officials, and researchers from the Department of Architecture at Ahmadu Bello University. The focus was on better understanding the evolution of settlements and town planning in the area.

The research method made it possible to analyse the influence of old settlement patterns on urban design and planning. This was in line with methods that emphasize the need to take into account the historical, cultural, physical, economic, and social aspects of urban systems and areas. This approach was based on the book Field instruction: A guide for social work students (Royse et al., 2017), which provides guidelines for research in communities. 
Table 1: Research questions, methods, analysis, and outcomes.

\begin{tabular}{|c|c|c|c|}
\hline Question & Method & Analysis & Outcome \\
\hline $\begin{array}{l}\text { 1) What is the historical narrative } \\
\text { explaining the development of } \\
\text { traditional Hausa settlement and } \\
\text { architectural patterns? }\end{array}$ & $\begin{array}{l}\text { - Secondary sources (eleventh- } \\
\text { nineteenth centuries) } \\
\text { - Household interviews } \\
\text { - Key informant interviews } \\
\text { - Participatory mapping }\end{array}$ & $\begin{array}{l}\text { - Descriptive statistics } \\
\text { - Trend analysis } \\
\text { - Historical/document analysis } \\
\text { - Features/spatial analysis } \\
\text { - Integration analysis }\end{array}$ & $\begin{array}{l}\text { Portrait and typologies of archi- } \\
\text { tecture, traditional settlements, } \\
\text { and town planning }\end{array}$ \\
\hline $\begin{array}{l}\text { 2) What factors influenced the } \\
\text { spatial arrangements, patterns, } \\
\text { and layout of Hausa settlements? }\end{array}$ & $\begin{array}{l}\text { - Reconnaissance surveys } \\
\text { - On-site observations } \\
\text { - Ground truthing } \\
\text { - Key informant interviews }\end{array}$ & $\begin{array}{l}\text { - Spatial analysis } \\
\text { - Integration analysis } \\
\text { - Architecture / housing design } \\
\text { analysis } \\
\text { - Participatory rapid analysis } \\
\text { - Thematic analysis }\end{array}$ & $\begin{array}{l}\text { Settlements' spatial patterns } \\
\text { and layout } \\
\text { Architectural styles and hou- } \\
\text { sing designs }\end{array}$ \\
\hline $\begin{array}{l}\text { 3) What are the perceptions of } \\
\text { the influence of traditional settle- } \\
\text { ments and architecture in Zaria } \\
\text { on integrating old and new set- } \\
\text { tlements in contemporary urban } \\
\text { design and planning? }\end{array}$ & $\begin{array}{l}\text { - Key informant interviews } \\
\text { - Deductive method }\end{array}$ & $\begin{array}{l}\text { - Settlement discourse analysis } \\
\text { - Integration analysis } \\
\text { - Spatial analysis } \\
\text { - Deductive analysis }\end{array}$ & $\begin{array}{l}\text { Perception of the influence of } \\
\text { traditional Zaria settlements } \\
\text { and architecture on integrating } \\
\text { old and new settlements }\end{array}$ \\
\hline
\end{tabular}

Sources: authors, based on Ibrahim (2015) and Narayanan (2015).

\subsection{Administering the questionnaire}

Questionnaires were administered to key informants in Zaria at ten intersections (near the mosque, market areas, and shops) to obtain information on architecture, urban design, and planning. This included types of building materials used, the influence of religion on architecture, religious symbols and design patterns, household composition, and how homestead land was divided. This approach was necessary because most residents of Zaria are Muslims, which makes it difficult to conduct surveys among Muslim women. Sixty-three questionnaires were administered to heads of household, who were first asked whether they lived in the old city or new town.

\subsection{Field observations of homestead settlements}

Surveys and observations of Hausa homestead settlement patterns were carried out and compared to old sketches from the colonial era. This information was used to create the illustrations and sketches in this article. The meanings of designs on facades and doors were discussed with key informants and researchers from the Department of Architecture at Ahmadu Bello University. This allowed deeper insight into the influence of traditional Hausa architecture and settlement patterns on planning new parts of towns. Sketches were used to illustrate Hausa settlement patterns.

\section{Hausa settlements}

Zaria is located at the southern tip of the Hausa ethnic area. Historically, Hausa settlements were feudal city-states encircled by a wall within enclosures with a market area and a monarchical government. Islam enriched the culture of the Hausa people when it was introduced from the Mali Empire in the fourteenth century. At the beginning of the nineteenth century, the British took over the administration of the former emirates. The establishment of a university campus has influenced traditional Hausa architecture and spatial organisation in greater Zaria, including in Bomo, which is another Hausa settlement north of Zaria.

\subsection{Geographical and historical context of Hausa settlements}

Hausa settlements on the savanna are usually located near streams. Sometimes wooded valleys alternate with ground sparsely covered with thorny shrubs. Before British colonial rule in Nigeria, the Hausa states had a pre-capitalist economy and a well-developed administrative centre. Technology included making pots and decorated calabashes (Kirk-Green, 1961). It is in this geographical area that Zaria, a major city in Kaduna State in Nigeria, previously known as Zazzau, evolved to become one of the seven Hausa city-states. According to the Nigeria's 2006 census, Zaria had a population of 406,099 


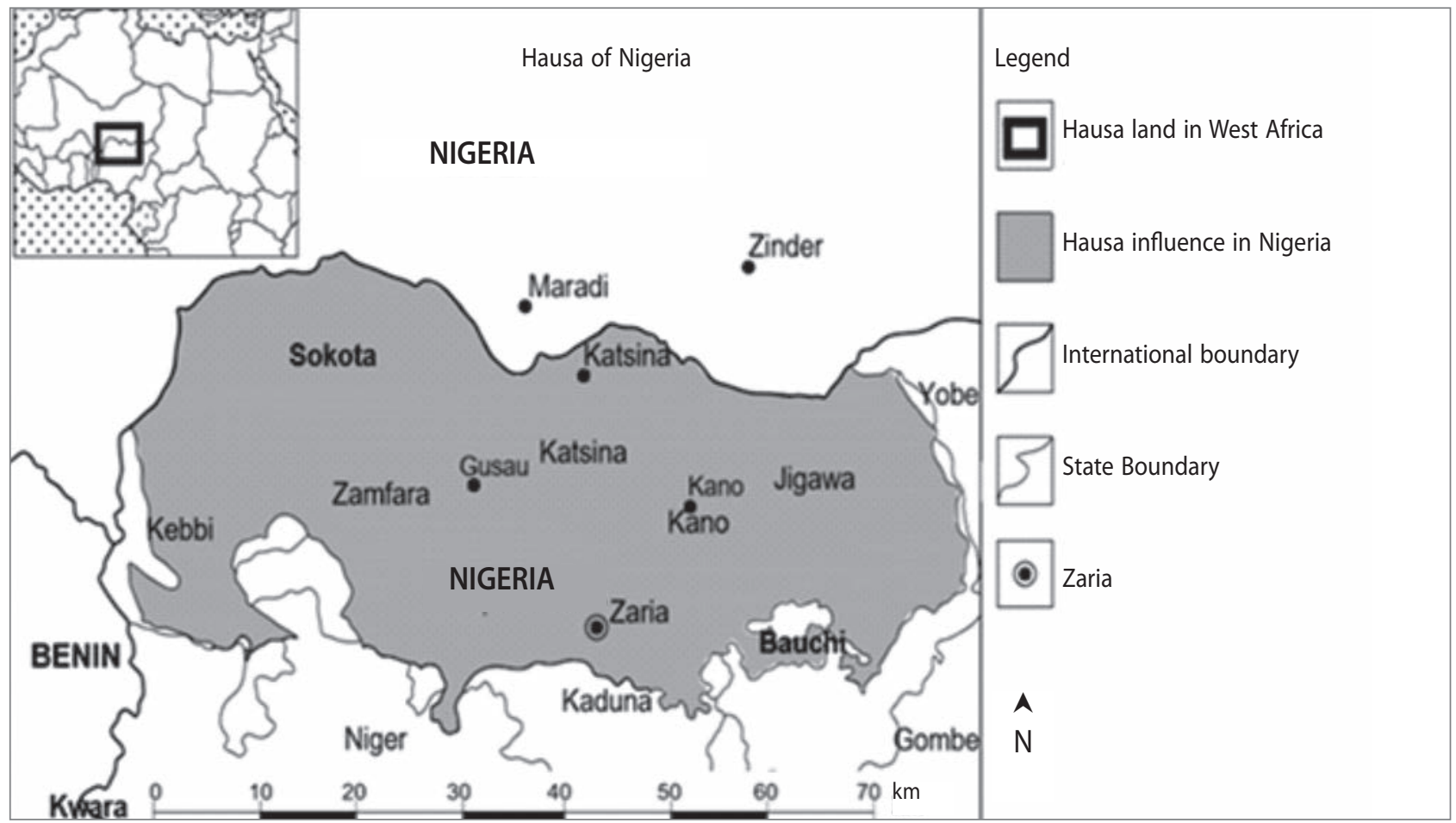

Figure 1: Location of Zaria and other Hausa city-states (illustration: authors, based on Ayodele and Odeyale, 2019).

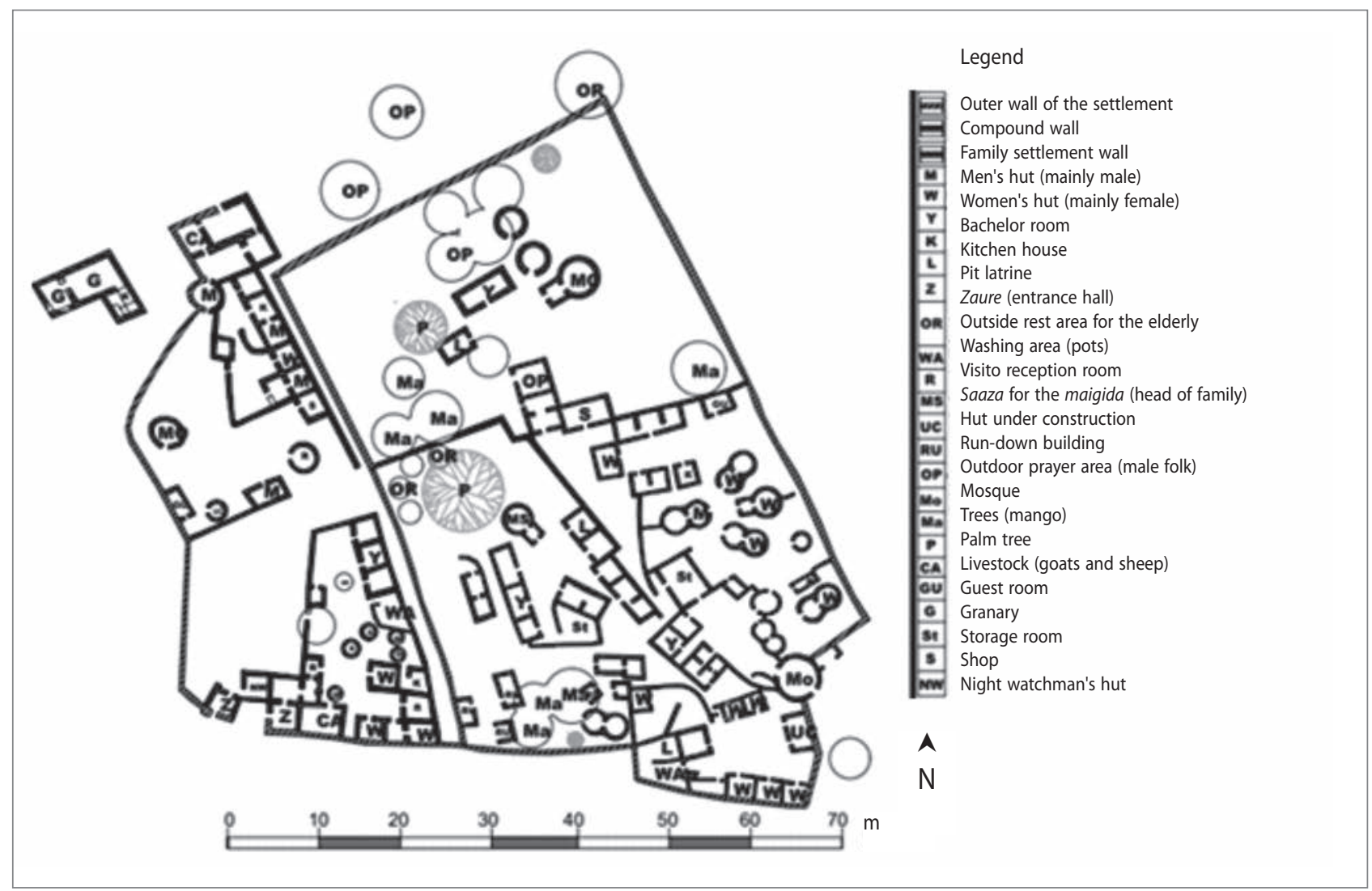

Figure 2: Spatial organization and layout of Hausa compounds (illustration: authors, based on Moughtin, 1964, and own field observations). 
people (Federal Office of Statistics, 2006). The city is a predominantly Hausa settlement with institutions, markets, and farming activities (Mảaruf, 2019).

\subsection{Emergence of Hausa settlement patterns}

Trans-Saharan trade coupled with the introduction of Islam from the Mali Empire in the fourteenth century had an enormous impact on Hausa settlement forms. A unique Hausa settlement pattern emerged from a hierarchy of rural settlement forms. This settlement system is based on an extended family system, and it is further sub-divided into several family compounds. Figure 2 shows a typical spatial plan of Hausa compounds with courtyards. It is a fenced settlement with several compact compounds. Security played a critical role in deciding how the Hausa settlement was nucleated. Zaria is a good example of a Hausa city encircled by defensive walls. The Zaria city wall was built in the eighteenth century (Adeyemi, 2008). The concentration of household members close to the market area is indicative of the defensive Hausa settlement style and a spatial layout structured for interaction.

\subsection{Influence of traditional Hausa architecture on contemporary settlement forms}

The connection between traditional Hausa architecture and contemporary settlement forms is based on three determining factors: Hausa culture, the environment, and the influence of climate. Hausa culture is based on history and tradition. It is centred on kinship and the social structure of the people (Madaua, 1968). Hausa building practices were dictated by Islam, in which the use of curvilinear and conical muddome roof structures was prevalent, as shown in Figure 3. Rapoport (1969) states that Hausa indigenous architecture is famous for its ribbed vaulting and dome-shaped sculpted external walls, which facilitate quicker runoff during heavy rain. In addition, individual dwellings were sometimes made of egg-shaped units called tubali to shed rainwater. Our observations on the ground showed that domed roofs were made of laboriously worked mud, cured under the sun and plastered for a monolithic finish (Beer \& Higins, 2000). The homestead is made up of circular and sometimes rectilinear units, but not perfect squares, which are linked to one another (Friedrich, 1982).

\subsection{Influence of climate and British colonial rule on traditional Hausa settlement patterns in Zaria}

Zaria is in West Africa's savannah area, characterized by a tropical climate with year-round warm weather. The wet season lasts

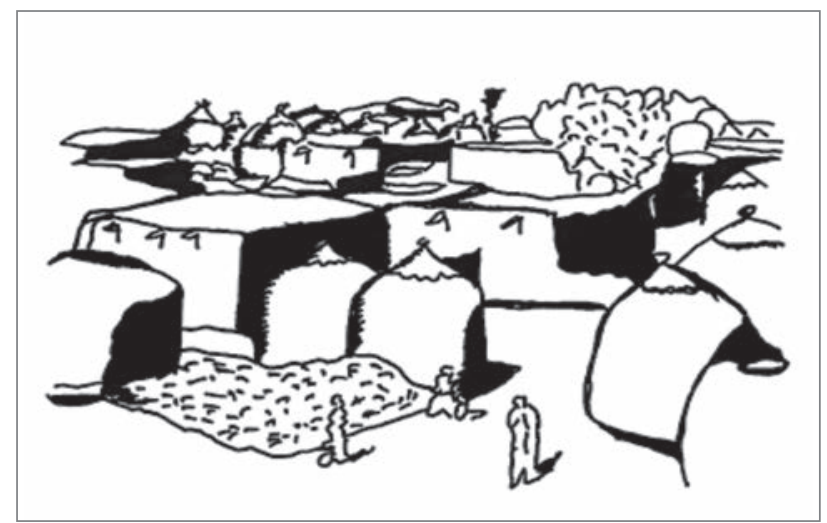

Figure 3: Hausa building practices with curvilinear and conical designs (illustration: authors, based on Rapoport, 1969).

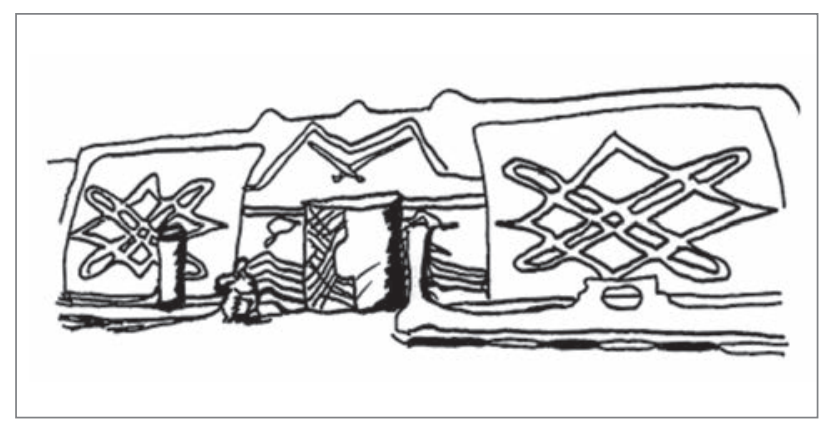

Figure 4: Typical Hausa decorations on walls with entrances (illustration: authors).

from March to September, and the dry season from October to February. In 2016 the average daily mean temperature was 25.6 ${ }^{\circ} \mathrm{C}$, with average precipitation of $117.6 \mathrm{~mm}$ and an average relative humidity of $69 \%$. The climate demands design solutions that reduce daytime heat and offer night-time cooling. For example, grass roofs are used for decorating and protecting the mud walls from heat and heavy rains. The openings under the houses and granaries provide shelter for chickens, dogs, and cats during severe heat and rain. These designs are still used in some traditional Hausa settlements (Beer \& Anne, 1982). Other decorations include murals (Figure 4). Decorations such as bold designs are engraved on walls with entrances. Such decorations can still be seen in contemporary Hausa cities such as Kano, Kazaure, and Zaria. Such decorative artworks constitute architectural heritage that is used in many parts of Zaria. The decorations have simple triangles with vertical, horizontal, and sometimes circular designs.

British rule in Nigeria started in the eighteenth century and peaked in the twentieth century. The colonial period introduced the concept of modern buildings and a change in perspectives on town planning (see Figure 5). Similarly, modern life in new towns outside the city was introduced by the colonial masters in what were called government reservation areas (GRAs), where modern durable building materials such as cement, concrete, and steel were commonly used. The com- 


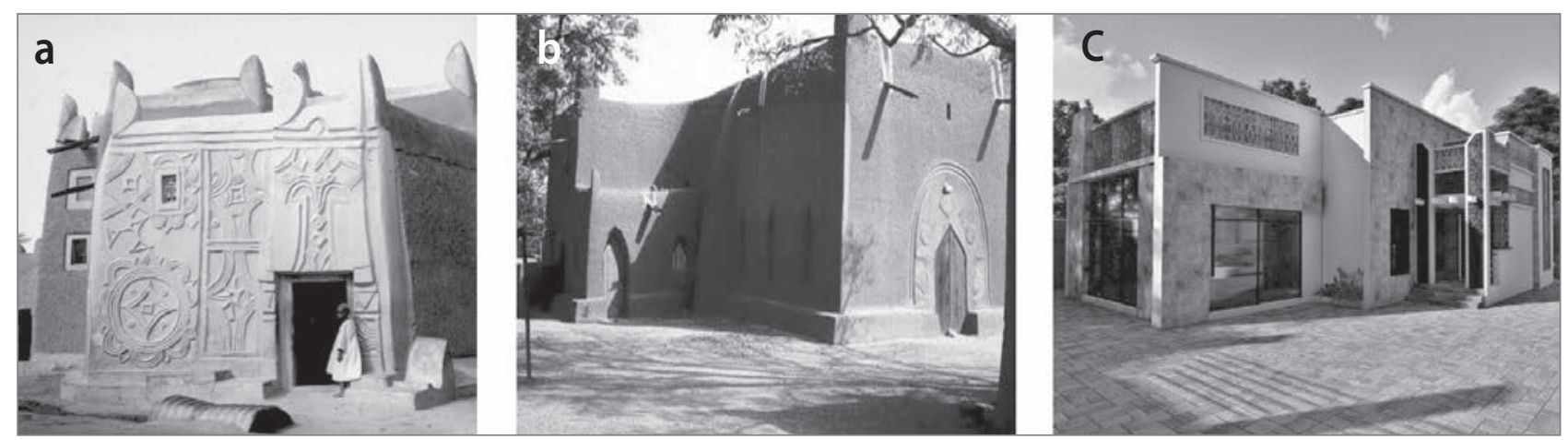

Figure 5: a) example of traditional Hausa architecture (photo: Isaac Samuel); b) example of colonial Hausa architecture (photo: Isaac Samuel); c) example of modern Hausa architecture (photo: Kalifa Rabiu).

bined effect was to make the residents of Zaria rethink the use of mud bricks as building materials and reinterpret architectural meaning in the spatial organization of homesteads. This led to concrete buildings in Zaria and paved roads. From an outside perspective, the traditional Hausa architecture and settlement form is challenged by the need to balance forces of change, modernity, culture, and heritage. It is no longer fashionable to build houses with mud bricks, but it is still fashionable to inscribe traditional Hausa design decorations on building entrances in Zaria (Adedokun, 2014).

The Hausa also started replacing the tracks and mud walls encircling dwelling units with street layouts during the colonial era. There is a separation of use for each space in a traditional Hausa settlement. For example, the houses of the Muslim women in purdah were arranged in such a way that each woman subordinated to her husband had a separate room. The pattern is typically African, but the rooms are arranged around a courtyard to provide for separation of the sexes. The entrance to the house is accessed via an entrance called the zaure, usually a hut where men sit and chat. Every family member has unrestricted access to the courtyard, and children can play there. In addition, at the edge of the courtyard there are huts for unmarried young men and male guests. The wife decorates her huts with her dowry gifts and other belongings. This is where she sleeps with her teenage children, and this is still practiced today. After an adult man has been allocated a piece of land, he first builds a wall, the zaure entrance hut, and a few sleeping huts as the need arises. These buildings are located inside the compound wall. The relatives' compounds are usually located next to each other. The network of compound walls produces the settlement pattern, which eventually becomes the city. The art of city making is a process in which cultural, social, economic, political, and physical components interact with each other. Lynch and Rodwin (1958) indicated that urban forms are a result of experiences, which are fundamental elements of human settlements, culture, and society. Hence, the organisation of urban spaces is crucial to producing social and spatial arrangements. In Zaria, the elements of urban form tend to influence its social, economic, and environmental settings, which is common in modern cities.

\section{Results and discussion}

\subsection{Transition from traditional to modern Zaria}

A sample of sixty-three respondents, including key informants from Zaria, were interviewed to assess their perceptions of the influence of traditional Hausa architecture and settlement forms in Zaria. Of these, 68\% (see Figure 6) indicated that traditional Hausa architecture and settlement patterns had declined but still exerted influence on building design and settlement. On the other hand, $32 \%$ of the respondents indicated that other factors (e.g. modern urban design and town planning principles) influenced building design and settlement. With respect of religious influence on modern architecture, 52\% believed that this shaped building styles in the past but to a lesser extent today. Meanwhile, $41 \%$ of the respondents viewed the building style of Hausa settlements as having incorporated western architectural styles; $7 \%$ were of the view that Hausa people have integrated international architectural cultures, thereby moderating the traditional religious influence on building styles and settlements. In terms of spatial organization and functional use of space, $65 \%$ of the respondents indicated that Hausa architecture is still influential. In contrast, $32 \%$ felt that this variable had moderate influence and 3\% that its impact was low. This was premised on the observation that modern town planning uses architectural and urban design concepts such as new urbanism, new mobility, new regionalism, and smart cities. The results agree with Akintoye (2010), who asserted that the major "ethnic groups in Nigeria have rich traditions" in which culture influences housing patterns as expressed by the varied components of the traditional housing structure and ideas integrated into modern architectural design and town planning (Bailey et al., 1977). Husukić and Zejnilović (2017: 96) found that "architectural remnants, or ruins in the urban fabric, instead of being unstable entities, have the potential to become drivers of a continuum." 


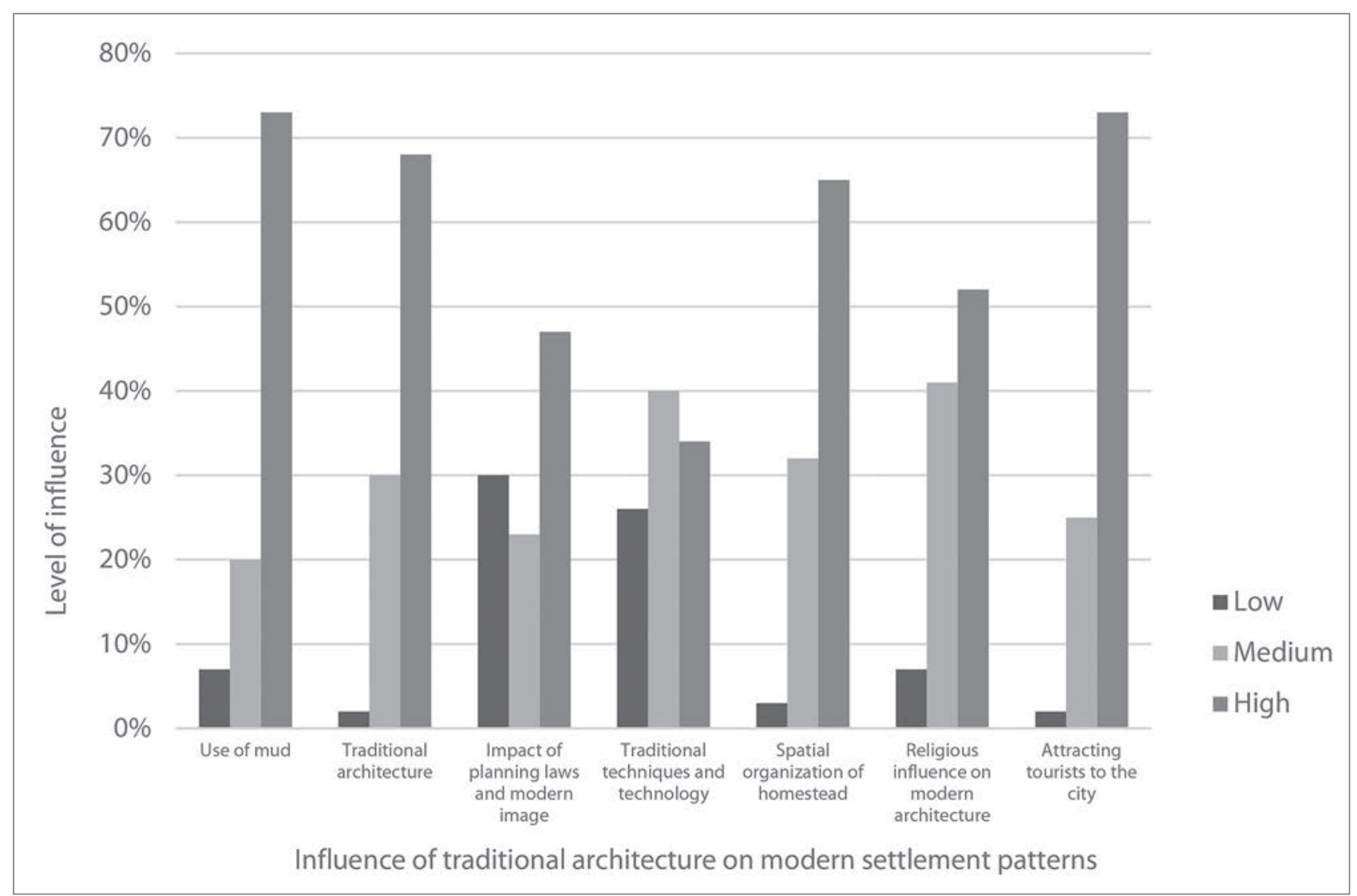

Figure 6: Respondents' perceptions of the influence of the traditional Hausa architecture on settlements (illustration: authors).

These themes resonate with the need to integrate old and new architecture in urban design and planning.

The study further revealed that current urban settlement patterns can be used to integrate components of Hausa spatial organization into new town layouts. This is because contemporary urban design and planning elements focus on the economical use of land, materials, and functional use of space. The study points to Islam as being one of the key rallying points for the continuation of Hausa traditional architecture and settlement patterns (Aluko, 2011). The emergence of the modern image of the city dweller and the fact that the government tried to integrate tradition into building regulations did not receive widespread acceptance from the respondents amid calls for more research. However, from the point of view of thermal comfort, form, and climate, mud still forms a substantial proportion of building materials across Nigeria (Evans, 1995; Danja et al., 2017). The respondents largely agreed (73\%) that traditional Hausa architecture and settlement forms have influenced building design. Façades and doors decorated with swords and crescent moons is a common vernacular architectural design and decoration heritage infused in some of the buildings in Zaria.
According to $65 \%$ of the respondents, building designs in Zaria were influenced by ideas taken from colonial rule and the introduction of modern building legislation in the nineteenth and twentieth centuries, in addition to the following:

- There was a reduction in large traditional Hausa compounds because of the introduction of town planning legislation that catered to smaller nuclear families with a house, a landscaped front yard, and parking space.

- New town developments reduced the influence of Hausa architecture and settlement patterns because of modern housing developments and economy-of-scale advantages.

- The reduction in Hausa traditional settlement patterns is because of the introduction of modern building materials such as cement, concrete, and steel as well as the introduction of street layouts.

- The reduction in the use of traditional mud-moulded decoration and the preference for modern materials resulted from the simpler use of modern materials.

- There was a reduction in grass-thatch roofs and their replacement with corrugated metal because of the simplicity of modern roofing material as opposed to the labour-intensive task of thatching. 
Table 2: Factors promoting integration and their significance.

\begin{tabular}{ll}
\hline Factor & Significance \\
\hline Urban spatial compactness & $\begin{array}{l}\text { Improvements in pedestrianization, reduced energy use, high quality of life for social interaction, } \\
\text { access to community services, sense of community, reduced travel need }\end{array}$ \\
\hline Mobility issues & $\begin{array}{l}\text { Reduced travel need, access to services, convenient natural environment and pedestrian-friendly rou- } \\
\text { tes, more public transportation }\end{array}$ \\
\hline Density considerations & $\begin{array}{l}\text { Good links between urban functions and spatial activities, compact development, efficient use of space } \\
\text { and urban land, reduced car ownership and travel need }\end{array}$ \\
\hline Land-use mix & $\begin{array}{l}\text { Safety on streets, increased accessibility, attractive local streets, more local creative interaction between } \\
\text { neighbours }\end{array}$ \\
\hline Diversity & $\begin{array}{l}\text { Rich social and cultural activities, traditional and religious beliefs, potential for promoting walkability } \\
\text { and close attractive urban landscapes }\end{array}$ \\
\hline Green urban development & $\begin{array}{l}\text { Favouring adaptation to micro-climatic conditions, green spaces for children to play, open spaces for } \\
\text { social interaction and promoting participatory spatial planning }\end{array}$ \\
\hline
\end{tabular}

Source: Dhingra \& Chattopadhyay (2016).

\subsection{Transition from Hausa mud huts to concrete}

The change from the use of mud to concrete or steel is based on durability, convenience, and flexibility (Taylor, 1998; Chokor, 2005). The uniqueness of the Hausa housing form is based on the availability of materials and the way homesteads are spatially organized. In this setup, mud is neither processed in a sophisticated manner nor fabricated like cement blocks. The Hausa, particularly in Zaria, preferred using tree branches, red laterite soil, and savannah grass, which are readily available in the vicinity. However, the loose nature of laterite soil, which is not as plastic as clay, obliged traditional Hausa builders to add grass, cow dung, and locust bean to laterite soil before moulding it to improve the plasticity of mud bricks. Because mud was readily available and cheap, this helped provide housing, but its drawback was that this construction method lacked flexibility, ground stabilization, and protection from erosion. Currently, such problems have been resolved with the use of building materials such as concrete, cement blocks, or cut stones (Rudofsky, 1964; Yiftachel, 1989). Thus, the transition from traditional building materials has an impact on the cultural heritage of the people of Zaria reflected in the integration of the old and new styles of buildings.

\subsection{Influence of external factors}

External moderating factors influenced the transformation of buildings and settlement patterns in Zaria. In terms of the traditional housing characteristics of the Hausa people, religion (jihads), daily living needs, the environment, and the need for security shaped housing and settlement patterns to a certain extent. Similarly, past and present socioeconomic factors made Zaria residents conceive dwelling characteristics and settlement forms from the perspective of change and modern town planning. A similar finding is made in respect of considering "the historical and essential relationship between people and place" in (re)constructing spatial identities in the Madir (Banja Luka, Bosnia and Herzegovina) and Ilsvika (Trondheim, Norway) neighbourhoods (Kuvač \& Schwai, 2017: 94).

\subsection{Influence of the spatial organization of the Hausa settlement pattern}

The study has shown that the traditional Hausa architecture and settlement patterns thrived in Zaria because of an enabling environment. The traditional architecture and settlement patterns were widespread in Hausa territory because of locally available building materials, sociocultural relevance, and affordability. A clear majority of the respondents (73\%) highlighted these factors. The influence of traditional Hausa architecture in shaping dwelling spaces is synonymous with the organization of space and functions in Hausa settlement areas in Zaria. Traditional Hausa architecture and settlement patterns influenced the separation of space in Hausa compounds, which represents a unique socioeconomic settlement pattern. The juxtaposition of homesteads in compounds shows a classic Hausa settlement pattern with distinct space functions and uses that can be integrated into current development forms and town planning.

\subsection{Factors promoting the integration of old and new settlement patterns in Zaria}

The case study of Zaria is based on factors that promote integrating traditional and modern settlement planning. The study has shown that the spatial organization elements of traditional Zaria settlement patterns can be integrated to a certain level with current urban design and spatial planning. The factors studied have an overlapping influence on sustainability from the social, economic, and environmental perspectives (see Table 2). 


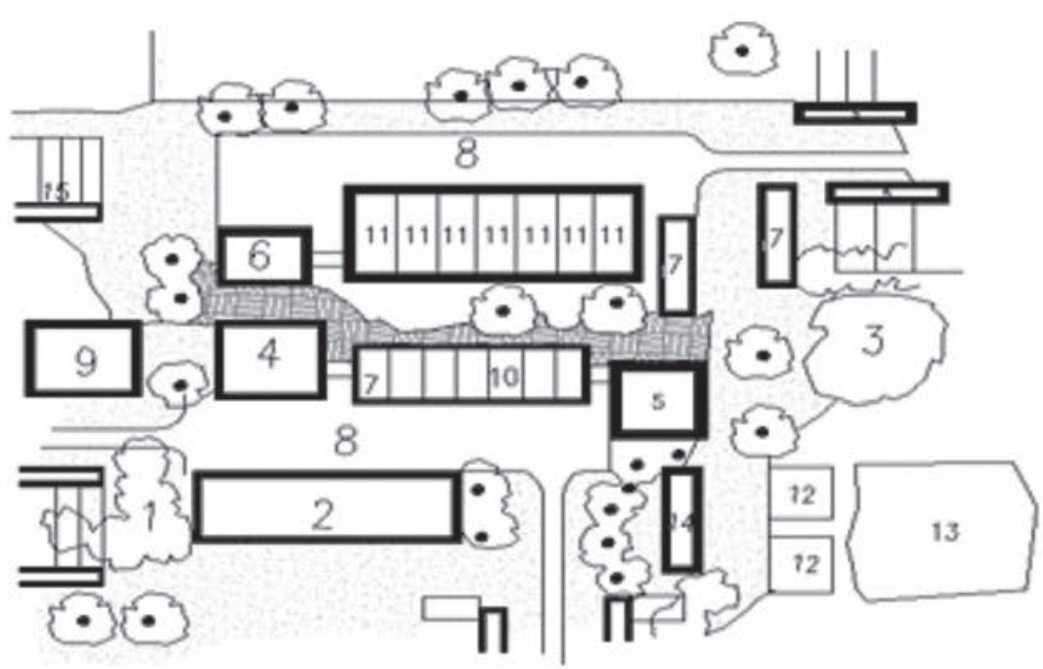

Legend

1: Neem and mango trees

2: Mosque and worship house

3: Vegetable garden

4: Head of family's house

5: Night watch house

6: Kitchen

7: Reception

8: Open space / parking

9: Outside resting place

10: Shops

11: Rooms for married women

12: Guest rooms

13: Outside play area

14: Outside storage house

15: Kitchen place

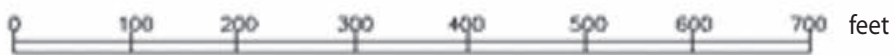

$\hat{\mathrm{N}}$

Figure 7: Integration of a traditional settlement pattern and township layout (illustration: authors).
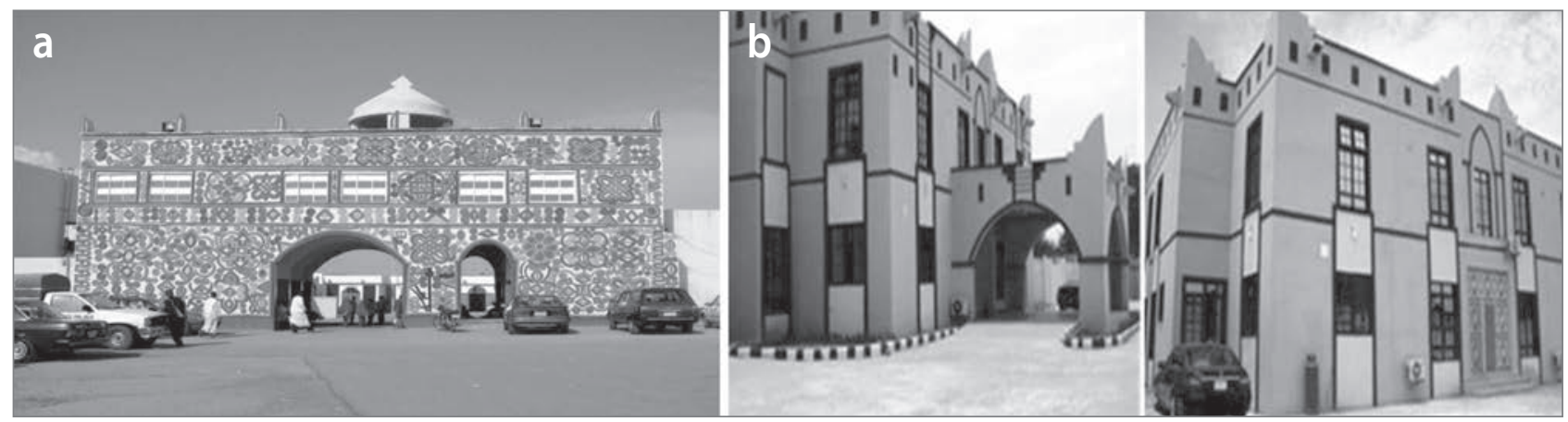

Figure 8: a) vernacular Hausa architecture in northern Nigeria; b) contemporary Hausa architecture with pinnacles (zanko) added at the top for a traditional look (photo: Shiraz Chakera).

From a modest wall city, Zaria evolved to become a conglomeration consisting of three main spatial areas: 1) the old walled city, 2) European-style non-Hausa residential areas, including government offices and markets, and 3) the new town, with non-native Hausa settlement areas. According to Ma'aruf (2019), each area was treated as a separate unit with respect to administration and town planning. The 1917 plan was crystallized in Zaria through a series of plans proposed by the colonial administration first in 1914 and revised in 1918 and 1939, all addressing the main European residential area (ERA) and associated land uses (Yigitcanlar et al., 2015).

\subsection{Application of traditional Zaria settlement patterns}

This section illustrates how the traditional Hausa settlement pattern in Zaria can be conceptualized to form part of the new town layout. The traditional Hausa open space, or dadali, in Zaria is comparable to green areas or parks in new towns. In addition, the Hausa homestead in Zaria can be compared to cul-de-sac layouts. The cul-de-sac concept can be likened to a gateway in the Hausa homestead, where control and security are exercised by a gatekeeper or night watchperson. Figure 7 shows an attempt to incorporate traditional Hausa settlement patterns and new town designs (Jackson, 2005). This resonates with spatial organization themes raised by Rezafar and Turk (2018: 85) with respect to urban design and planning being "a multidimensional and complex subject that can be evaluated both formally and symbolically, requiring assessments of individuals' experience, behaviour patterns, and subjective consideration and meaning at the same time as those of physical characteristics, natural setting, land-use, circulation systems, and built forms." Note that there are lessons that can be learned from the influence of the traditional Zaria pattern with respect to similarities and differences in settlements' spatial organization. There are many contemporary examples of incorporating traditional settlement designs. 
Table 3: Factors influencing traditional and new town layouts in Zaria.

\begin{tabular}{|c|c|c|c|c|}
\hline \multirow[t]{2}{*}{ Factors } & \multicolumn{2}{|c|}{ Differences } & \multicolumn{2}{|c|}{ Similarities } \\
\hline & Traditional patterns & New design concept & Traditional patterns & New design concept \\
\hline \multirow{4}{*}{$\begin{array}{l}\text { Adaptation } \\
\text { to environment }\end{array}$} & $\begin{array}{l}\text { Location at a suitable local } \\
\text { site }\end{array}$ & $\begin{array}{l}\text { Site must meet necessary } \\
\text { construction requirements }\end{array}$ & $\begin{array}{l}\text { Sustainability of site for } \\
\text { residency and not flood- } \\
\text { prone }\end{array}$ & $\begin{array}{l}\text { Residential buildings in } \\
\text { low flood-risk areas }\end{array}$ \\
\hline & Building materials local & $\begin{array}{l}\text { Building materials import- } \\
\text { ed or processed }\end{array}$ & Wood from nearby forest & Polished imported wood \\
\hline & $\begin{array}{l}\text { Considerations for seasonal } \\
\text { temperature changes }\end{array}$ & $\begin{array}{l}\text { Site suitability may depend } \\
\text { on engineering } \\
\text { requirements }\end{array}$ & $\begin{array}{l}\text { Seasonal temperature, } \\
\text { precipitation, and wind } \\
\text { may determine building } \\
\text { orientations }\end{array}$ & $\begin{array}{l}\text { Building orientation based } \\
\text { on direction of sun, pre- } \\
\text { vailing winds, } \\
\text { temperature }\end{array}$ \\
\hline & $\begin{array}{l}\text { Trees are kept, providing } \\
\text { shade }\end{array}$ & $\begin{array}{l}\text { Trees planted where } \\
\text { necessary }\end{array}$ & $\begin{array}{l}\text { Building around existing } \\
\text { trees }\end{array}$ & $\begin{array}{l}\text { Trees planted for specific } \\
\text { functions }\end{array}$ \\
\hline \multirow{3}{*}{ Settlement forms } & $\begin{array}{l}\text { Popular culture from same } \\
\text { ethnic group }\end{array}$ & $\begin{array}{l}\text { Integration irrespective of } \\
\text { ethnic groups }\end{array}$ & $\begin{array}{l}\text { Cultural consideration for } \\
\text { social integration }\end{array}$ & $\begin{array}{l}\text { Integration of people from } \\
\text { all walks of life }\end{array}$ \\
\hline & $\begin{array}{l}\text { Size of building depends on } \\
\text { function and use }\end{array}$ & $\begin{array}{l}\text { Buildings can incorporate } \\
\text { many floors }\end{array}$ & $\begin{array}{l}\text { Size of building is } \\
\text { determined by use }\end{array}$ & $\begin{array}{l}\text { Size of building } \\
\text { determined by funds }\end{array}$ \\
\hline & $\begin{array}{l}\text { Residential compound } \\
\text { clustered together }\end{array}$ & $\begin{array}{l}\text { Residential buildings based } \\
\text { on zoning }\end{array}$ & $\begin{array}{l}\text { Urbanization more gradual } \\
\text { than spontaneous }\end{array}$ & $\begin{array}{l}\text { Urbanization by establish- } \\
\text { ing townships and new } \\
\text { towns }\end{array}$ \\
\hline \multirow{3}{*}{ Architectural style } & $\begin{array}{l}\text { Building techniques similar } \\
\text { for all types of buildings }\end{array}$ & $\begin{array}{l}\text { Building techniques adapt- } \\
\text { ed to building styles }\end{array}$ & $\begin{array}{l}\text { Building techniques } \\
\text { rudimentary }\end{array}$ & $\begin{array}{l}\text { Building with aid of } \\
\text { technology }\end{array}$ \\
\hline & Local materials & $\begin{array}{l}\text { Imported or industrial } \\
\text { materials }\end{array}$ & Local building materials & $\begin{array}{l}\text { Imported or local } \\
\text { materials }\end{array}$ \\
\hline & $\begin{array}{l}\text { Decoration based on cus- } \\
\text { toms or cultural practices }\end{array}$ & $\begin{array}{l}\text { Decoration based on } \\
\text { research or innovations }\end{array}$ & $\begin{array}{l}\text { Decorations are social and } \\
\text { cultural expressions }\end{array}$ & $\begin{array}{l}\text { Decoration is manifesta- } \\
\text { tion of popular culture } \\
\text { and IT }\end{array}$ \\
\hline \multirow{3}{*}{ Spatial organization } & $\begin{array}{l}\text { Allocation of open spaces } \\
\text { and functions based on } \\
\text { social and cultural needs }\end{array}$ & $\begin{array}{l}\text { Allocation of open spaces } \\
\text { based on scientific calcu- } \\
\text { lations }\end{array}$ & $\begin{array}{l}\text { Allocation of open spaces } \\
\text { based on social and activity } \\
\text { needs }\end{array}$ & $\begin{array}{l}\text { Allocation of open space } \\
\text { based on land use and } \\
\text { zoning }\end{array}$ \\
\hline & $\begin{array}{l}\text { Arrangement of dwelling } \\
\text { spaces based on clan, } \\
\text { marital status, need }\end{array}$ & $\begin{array}{l}\text { Open space for shared use } \\
\text { by children }\end{array}$ & $\begin{array}{l}\text { Allocation of dwelling } \\
\text { spaces based on current } \\
\text { dwelling needs }\end{array}$ & $\begin{array}{l}\text { Allocation of dwelling } \\
\text { spaces based on } \\
\text { residential density }\end{array}$ \\
\hline & $\begin{array}{l}\text { Allocation of building } \\
\text { spaces based on extended } \\
\text { family size }\end{array}$ & $\begin{array}{l}\text { Allocation of dwelling } \\
\text { spaces is demand driven }\end{array}$ & $\begin{array}{l}\text { Allocation of dwelling units } \\
\text { based on housing needs }\end{array}$ & $\begin{array}{l}\text { Allocation of dwelling } \\
\text { units based on } \\
\text { development and } \\
\text { business proposals }\end{array}$ \\
\hline
\end{tabular}

Source: authors.

Traditional Hausa settlement designs and planning principles can also be applied generally in town planning and sustainability management. The differences and similarities of factors influencing traditional and new town layout concepts in Zaria are similar to those in studies from elsewhere (Mandanipour, 1996; Boerefijn, 2016).

\section{Conclusion}

The study shows that traditional Hausa architecture and settlement patterns have influenced the spatial organisation of settlements in Zaria (Falahat, 2013). Traditional Hausa settlement patterns can be integrated into new town designs by taking into account factors that are similar in both old and new town planning concepts. The study has also shown that the use of cheaper building materials such as a mixture of laterite and clay, wood, stone, thatched roofs, and appropriate design principles to enhance privacy and comfort are rooted in traditional Hausa architecture and settlement forms. However, the Zaria settlement pattern cannot be applied completely because of informality of acquiring land in the past, which is not possible under current systems. Historically, land was primarily acquired through traditional systems that did not incorporate formal registration of property rights. Currently, land in Zaria is predominantly acquired through formal land registration systems. The study has shown that to apply the architecture and settlement patterns in Zaria elsewhere, the solution must be relevant to the sociocultural environment 
of the people. The impact of modernization cannot be underestimated, and the importance of cross-blending traditional and modern concepts of architecture and settlement planning cannot be overemphasized. However, further research is needed to understand the influence and framework for integrating the two models. Traditional settlement forms such as those of the Hausa people in Zaria reflect people's aspirations with respect to their social, economic, educational, religious, and cultural values. Town planners, architects, and developers can study the modalities of integrating traditional architecture and other cultural heritage into new settlement plans to promote community cohesion, heritage, and best practices in urban design and planning.

Peter Bikam, University of Venda, School of Environmental Sciences, Department of Urban and Regional Planning, Thohoyandou, South Africa

E-mail: peter.bikam@univen.ac.za

James Chakwizira, University of Venda, School of Environmental Sciences, Department of Urban and Regional Planning, Thohoyandou, South Africa

E-mail: james.chakwizira@univen.ac.za

\section{References}

Adedokun, A. (2014) Incorporating traditional architecture into modern architecture: Case study of Yoruba traditional architecture. British Journal of Humanities and Social Sciences, 11(1), pp. 39-45.

Adeyemi, A. E. (2008) Meaning and relevance in Nigerian traditional architecture: The dialectics of growth and change. Public Lecture Series, 1(21), pp. 1-33.

Akintoye, A. S. (2010) A history of the Yoruba people. Dakar, Amalion Publishing.

Aluko, O. (2011) Functionality of the town planning authorities in effecting urban and regional planning laws and control in Nigeria: The case of Lagos State. African Research Review, 5(6), pp. 156-171. DOI: 10.4314/afrrev.v5i6.14

Astrolabe, A. M. O. (2002) Architecture in Nigeria and practice for sustainable environmental development. A comparative study of modern and indigenous housing strategies. Journal of the Nigerian Institute of Architects, 2(1), pp. 261-272.

Ayodele, E. I. \& Odeyale, T. O. (2019) Designing for cultural revival: African housing in perspective, Space and Culture, pp. 1-8. DOI: $10.1177 / 1206331218825432$

Bailey, J. W., Heyden, D. \& Gendrop, P. (1977) Pre-Columbian architecture of Mesoamerica. In: Nervi, P. L. (ed.) History of world architecture series. New York, Harry N. Abrams. DOI: 10.2307/776099

Barau, A. S., Maconachie, R., Ludin, A. M. N. \& Abdulhamid, A. (2015) Urban morphology dynamics and environmental change in Kano, Nigeria. Land Use Policy, 42, pp. 307-317. DOI: 10.1016/j.landusepol.2014.08.007

Beer, A. R. \& Anne, R. (1982) The external environment of housing areas. Built Environment, 8(1), pp. 25-29.

Beer, A. R. \& Higgins, C. (2000) Environmental planning for site development: A manual for sustainable local planning and design. New York, Routledge.
Boerefijn, W. (2016) About the ideal layout of the city street in the twelfth to sixteenth centuries: The myth of the renaissance in town building. Journal of Urban History, 42(5), pp. 938-952. DOI: $10.1177 / 0096144214566983$

Buchanan, K. M. \& Pugh, C. J. (1955) Land and people in Nigeria. London, Hodder \& Stoughton.

Chokor, B. A. (2005) Changing urban housing form and organization in Nigeria: lesson for community planning. Planning Perspectives, 20(1), pp. 69-96. DOI:10.1080/0266543042000300546

Danja, I. I., Dalibi, G. S. \& Safarov. A. (2017) Factors shaping vernacular architecture of Northern Nigeria. Journal of Building and Sustainability, 1(1), pp. 36-47.

Deckro, F. R. \& Hebert, E. J. (2003) Modeling diminishing returns in project resource planning. Computers and Industrial Engineering, 44(1), pp. 19-33. DOI: 10.1016/S0360-8352(02)00182-1

Dhingra, M. \& Chattopadhyay, S. (2016) Advancing smartness of traditional settlements-case analysis of Indian and Arab old cities. International Journal of Sustainable Built Environment, 5(2), pp. 549-563. DOI: 10.1016/j.ijsbe.2016.08.004

Denyer, S. (1978) African traditional architecture. London, Heineman Educational Books.

Dmochowski, R. Z. (1990) An introduction to Nigerian traditional architecture, 1-3. Lagos, The National Commission for Museums and Monuments.

Dobronravin, N. (2013) "Classical Hausa" glosses in a nineteenth-century Qur'anic manuscript: A case of "translational reading" in Sudanic Africa? Journal of Qur'anic Studies, 15(3), pp. 84-122. DOI: 10.3366/jgs.2013.0115

Evans, B. (1995) Experts and environmental planning. Aldershot, UK, Avebury.

Falahat, S. (2013) New town versus old town: $A$ study on urban pattern and energy efficiency. Berlin, Universitätsverlag TUB.

Federal Office of Statistics (2006) Population census. Abuja.

Friedrich, S. W. (1982) Traditional housing in Africa cities. A comparative study of houses in Zaria, Ibadan and Marrakech. New York, John Wiley and Sons.

Husukić, E. \& Zejnilović, E. (2017) The environmental aesthetics of Sarajevo: A city shaped by memory. Urbani izziv, 28(1), pp. 96-106. DOI: 10.5379/urbani-izziv-en-2017-28-01-002

Hutchison, D. \& Sterbenz, G. J. P. (2018) Architecture and design for resilient networked systems. Computer Communications, 131 (2018), pp. 13-21. DOI: 10.1016/j.comcom.2018.07.028

Ibrahim, R. (2015) Elements of traditional urban form in the Arab world. Available at: https://www.linkedin.com/pulse/elements-traditional-urban-form-arab-world-rafik-ibrahim (accessed: 19 Oct. 2015).

Jackson, M. S. (2005) Cape colonial architecture, town planning, and the crafting of modern space in South Africa. Africa Today, 51(4), pp. 33-54. DOI: 10.1353/at.2005.0042

Kirk-Green, A. (1961) Decorated houses in Zaria. Nigeria Magazine, 68, pp. 52-78.

Kuvač, I. \& Schwai, M. (2017) Three elements in the construction of spatial identities in Mađir (Banjaluka, Bosnia and Herzegovina) and Ilsvika (Trondheim). Urbani izziv, 28(1), pp. 83-95. DOI: 10.5379/urbani-izziv-en-2017-28-01-001

Lynch, K. \& Rodwin, L. (1958) A theory of urban form. Journal of the American Institute of Planners, 24(4), pp. 201-214. DOI: $10.1080 / 01944365808978281$ 
Ma'aruf, S. (2019) The paradox of post-colonial urban growth in the city of Zaria, Nigeria. Journal of Geography and Regional Planning, 12(1), pp. 1-9. DOI: 10.5897/JGRP2018.0714

Madaua, I. (1968) Hausa customs. Zaria, Nigeria, Northern Nigerian Publishing Company.

Mandanipour, A. (1996) Design of urban space: An enquiry into a socio-spatial process. New York, John Wiley \& Sons.

Markus, B. (2016) Review of courtyard house in Nigeria: Definitions, history, evolution, typology, and functions. AFRREV STECH: An International Journal of Science and Technology, 5(2), pp. 103-117.

DOI: 10.4314/stech.v5i2.8

Moughtin, J. C. (1964) The traditional settlements of the Hausa people. Town Planning Review, 35(1), pp. 21-22.

DOI: 10.3828/tpr.35.1.y03303u5115t1711

Narayanan, Y. (2015) Religion, heritage and the sustainable city: Hinduism and urbanisation in Jaipur. London, Routledge. DOI: 10.4324/9780203750797

Olotuah, A. O. (2000) The challenge of housing in Nigeria. Akinbamijo, O.B., Fawehinmi, A. S., Ogunsemi, D. R. \& Olotuah, A. O. (Eds.) Effective housing in 21st century Nigeria, Akure, pp. 16-21, Environmental Forum, Federal University of Technology, Department of Architecture, Nigeria.

Rapoport, A. (1969) House form and culture. Englewood Cliffs, NJ, Prentice-Hall.

Rezafar, A. \& Turk, S. S. (2018) Urban design factors involved in the aesthetic assessment of newly built environments and their incorporation into legislation: The case of Istanbul. Urbani izziv, 29(2), pp. 83-95. DOI: 10.5379/urbani-izziv-en-2018-29-02-002

Rowan, K. R. (1981) Formal and spatial variations in a traditional wall city of Zaria, Nigeria. Master's thesis. Cambridge, MA, Massachusetts Institute of Technology, Faculty of Architecture.

Royse, D., Dhooper, S. \& Rompf, E. (2007) Field instruction: A guide for social work students. 5th ed. Boston, Pearson Education.

Rudofsky, B. (1964) Architecture without architects: A short introduction to non-pedigreed architecture. New York, Museum of Modern Art.

Taylor, A. J. (1998) Domestic agenda setting, 1947-1994. Legislative Studies Quarterly, 23(3), pp. 373-397. DOI: 10.2307/440359

Yiftachel, O. (1989) Towards a new typology of urban planning theories. Environment and Planning, 16(1), pp. 23-39. DOI: 10.1068/b160023

Yigitcanlar, T., Kamruzzaman, M. \& Teriman, S. (2015) Neighborhood sustainability assessment: Evaluating residential development sustainability in a developing country context. Sustainability, 7(3), pp. 25702602. DOI:10.3390/su7032570 